J. AMER. SOC. HORT. SCI. 118(6):868-872. 1993.

\title{
Flowering, Vegetative Growth, Yield, and Fruit Quality in Muskmelons under Saline Conditions
}

\author{
Samuel Mendlinger \\ The Institutes for Applied Research, Ben-Gurion University of the Negev, P.O. Box 1025, \\ Beer-Sheva, Israel \\ Michael Fossen \\ Obst-und Gemüsebau Institut der Universität Bonn, Bonn, Germany \\ Additional index words. breeding, Cucumis melo, cultivation, salt tolerance
}

\begin{abstract}
The muskmelon (Cucumis melo L.) cultivars Topmark, Galia, No. 1, and BG-84-3 (BG) were examined in a field test for the influence of increased salt concentration $(700,2500,5000,7500$, and $10,000 \mathrm{ppm})$ on flower production, vegetative growth, yield, and fruit quality. Increased salinity did not affect the number or timing of staminate and pistillate flowers produced. Increased salinity significantly and to the same extent reduced vegetative growth in the four cultivars. Increased salinity did not affect the number of fruit produced in the four cultivars but reduced mean fruit weight in three. Mean fruit weight and yield of 'BG' were not reduced; i.e., 'BG' was salt tolerant. Increased salinity increased the soluble solids concentration and slightly improved fruit appearance of all cultivars.
\end{abstract}

Agricultural production under irrigation is becoming more important worldwide. Increasingly, low-quality saline water must be used for irrigation. The adverse effects associated with increasing salinity on most plants is well documented (Greenway and Munns, 1980; Mass and Hoffman, 1977; Pasternak, 1987). Before using saline water for effective and efficient irrigation in a crop, it is necessary to understand the crop's response and evaluate cultivar differences to a range of salinity levels. Necessary detailed knowledge, depending on the crop, may include germination, seedling establishment, vegetative growth and growth rate, flower production (timing and number), yield characteristics (such as fruit count and individual weight), and product quality.

In many arid and semiarid regions of the world, melon is an important horticultural crop often cultivated under irrigation. However, our knowledge of the effects of various salt concentrations on economically important characteristics in this crop is limited. Some aspects of vegetative growth and yield have been investigated in controlled pot experiments or in a greenhouse (Meiri et al., 1982; Nukaya et al., 1980a, 1980b). Other studies (Mangal et al., 1988; Mendlinger and Pasternak, 1987; Nerson and Paris, 1984; Pasternak, 1992; Shannon and Francois, 1978; Shannon et al., 1984) have established that cultigens can vary from being salt sensitive to moderately salt tolerant. However, to date, no comprehensive study has been conducted that examined the overall effects of salinity levels on vegetation growth, flowering, yield, and fruit quality in diverse melon cultivars. In this study, we examined these characteristics in four melon cultivar grown at five levels of salinity in the field.

\section{Materials and Methods}

The field trial was conducted at the Ramat Hanegev Field Station, Israel. The station is situated in the middle of the Negev desert (annual rainfall $80 \mathrm{~mm}$ ) and the soil is a sandy loam. The four cultivars tested were 'No. 1', an open pollinated Israeli muskmelon reported to be moderately salt tolerant; 'Topmark', an

Received for publication 30 Mar. 1992. Accepted for publication 26 Feb. 1993. The cost of publishing this paper was defrayed in part by the payment of page charges. Under postal regulations, this paper therefore must be hereby marked advertise ment solely to indicate this fact.
American muskmelon reported to be moderately salt sensitive; 'Galia', an Israeli $\mathrm{F}_{1}$ muskmelon reported to be very salt sensitive; and 'BG-84-3' ('BG'), an $\mathrm{F}_{1}$ hybrid bred by S.M. for salt and heat tolerance (unpublished data). The five irrigation salinity levels were 700 (control), 2500, 5000, 7500, and 10,000 ppm. The field was designed in a Latin square for the five salinity treatments, i.e., with five replications for each treatment. Six raised beds per treatment per block were established: the first and sixth beds served as borders and the second through fifth were the four cultivars. Each raised bed was $2 \mathrm{~m}$ wide and $10 \mathrm{~m}$ long with a single drip line containing 2-liter $\cdot \mathrm{h}^{-1}$ drippers spaced $0.5 \mathrm{~m}$ apart running down the middle of each bed. The field was pretreated with $280 \mathrm{~kg}$ $\mathrm{N}$ and $140 \mathrm{~kg} \mathrm{P}$ per ha.

All cultivars were sown on 19 May at a density of 8 seeds per running meter ( $12.5 \mathrm{~cm}$ apart). At day 21 , all beds were thinned to six plants per meter, a plant density used for commercial production during the summer growing season. Fresh water $(700 \mathrm{ppm}$ salt) was supplied for irrigation to all treatments during germination and establishment. At day 28, all salinity treatments began with an initial irrigation of $50 \mathrm{~mm}$ of the appropriate salinity treatment. The required salinity levels were induced by injecting the appropriate amount of concentrated $3 \mathrm{NaCl}: 1 \mathrm{CaCl}$ brine solution (molar ratio) into the control water, through which nutrients also were applied (Pasternak et al., 1986a). The salt concentration of each treatment was examined at every irrigation. The irrigation and fertilization regimes were those recommended for melons in the region. Fertigation was applied three times a week.

At the onset of flowering, the number of staminate and pistillate flowers and the number of fruit $>5 \mathrm{~cm}$ long were counted three times a week for 4 weeks in a $2-\mathrm{m}^{2}$ randomly chosen plot in each bed. No significant interaction was found between census period and flower production or cultivar, and the results presented are pooled over all 11 census dates. At day 65 after sowing, one plant from each bed was sampled, and length, number of nodes and side branches on the main stem, and fresh and dry biomass of all aboveground vegetative material were recorded.

All fruit were harvested at full slip. Each fruit was weighed, percentage netting was determined, and appearance was rated. Percentage netting $(0 \%, 10 \%, 25 \%, 50 \%, 75 \%$, or $100 \%)$ was defined as the amount of melon surface covered by the net. Appearance and marketability of the fruit were rated on a scale of 
1 to 5 , with $1=$ perfect and $5=$ unmarketable. The same two people rated netting and appearance of all fruit. During the middle of the harvest, five randomly selected fruit per bed were brought to the laboratory for fruit constituent analyses. A longitudinal slice was taken from each fruit and the juice was used to analyze total soluble solids concentration (SSC), reducing sugars, electrical conductivity (EC), acidity, and $\mathrm{pH}$.

Soil samples were taken from each treatment in each block 4 weeks after the salinity treatments began. Each sample was taken directly under a dripper (chosen at random) from four depths: 5 to 15,15 to 30,30 to 60 , and 60 to $90 \mathrm{~cm}$.

Statistical analyses were performed on the data using the appropriate analysis of variance for Latin squares, regression, or correlation.

\section{Results}

Soil salinity. The EC of the soil extracts increased significantly with increasing salinity of the irrigation water $(r=0.95, P \leq 0.01)$, but decreased significantly $(r=0.96, P \leq 0.05)$ with depth (Table 1). The soil EC at 60 to $90 \mathrm{~cm}$ was half of that at 5 to $15 \mathrm{~cm}$. In the three highest salinity treatments $(5000,7500$, and $10000 \mathrm{ppm})$ soil EC levels were consistently lower than the EC of the irrigation water, whereas, in the 700- and 2500-ppm treatments, soil samples from 5 to 15 and 15 to $30 \mathrm{~cm}$ had a higher EC than the irrigation water. These results were consistent with soil salinity levels previously found using the same experimental design ( Mendlinger and Pasternak, 1992; Pasternak et al., 1986b).

Flower and early fruit count. Increased salinity did not affect the number or the timing of staminate and pistillate flowers or the number of fruit produced (Table 2). However, across the salinity levels, there were significant differences among the four cultivars in all three characteristics. 'No. 1' had more staminate flowers than the other three cultivars and 'Topmark' had the most and 'Galia' the fewest pistillate flowers. The number of staminate flowers produced was correlated with time, with all four cultivars exhibiting a significant positive correlation between census period and the number of flowers at each census period $(r \geq 0.94, P \leq 0.01)$.

The distribution of pistillate flowers over time differed among cultivars (Fig. 1). 'Galia' and 'No. 1' had strong bimodal distributions, the two modes being $\approx 2$ weeks apart, and no significant correlations were found between census and flower number. 'Topmark' exhibited a linear increase in the number of flowers over the census period, and a significant correlation $(r=0.88, P=$ $0.01)$ was found between them. 'BG' exhibited an intermediate distribution; although flowering was slightly bimodal, flower

Table 1. Electrical conductivity (EC) of soil samples at four depths over five salinity treatments; $\mathbf{n}=3$.

\begin{tabular}{|c|c|c|c|c|c|c|}
\hline \multirow{4}{*}{$\begin{array}{l}\text { Depth } \\
(\mathrm{cm})\end{array}$} & \multicolumn{5}{|c|}{$\mathrm{EC}\left(\mathrm{dS} \cdot \mathrm{m}^{-1}\right)$} & \multirow[b]{4}{*}{ Mean $^{2}$} \\
\hline & \multicolumn{5}{|c|}{ Salt concentration of irrigation water, ppm } & \\
\hline & 700 & 2500 & 5000 & 7500 & 10,000 & \\
\hline & $(1.1)$ & $(4.0)$ & $(8.0)$ & $(12.0)$ & $(16.0)$ & \\
\hline $5-15$ & 3.98 & 5.42 & 5.81 & 6.04 & 7.68 & $2.32 \mathrm{~b}$ \\
\hline $15-30$ & 2.34 & 5.00 & 5.20 & 6.24 & 6.76 & $4.10 \mathrm{ab}$ \\
\hline $30-60$ & 1.66 & 3.60 & 3.16 & 4.46 & 5.58 & $4.23 \mathrm{ab}$ \\
\hline $60-90$ & 1.30 & 2.36 & 2.76 & 4.42 & 3.90 & $5.34 \mathrm{a}$ \\
\hline Mean $^{2}$ & $2.32 \mathrm{~b}$ & $4.10 \mathrm{ab}$ & $4.24 a b$ & $5.34 \mathrm{a}$ & $5.98 \mathrm{a}$ & \\
\hline \multicolumn{7}{|l|}{ Significance } \\
\hline Depth & *** * & & & & & \\
\hline Salinity treatment & $* * *$ & & & & & \\
\hline Interaction & NS & & & & & \\
\hline
\end{tabular}

${ }^{\bar{z}}$ Mean separation at $P \leq 0.05$ by LSD

${ }_{\mathrm{Ns},}^{* * *}$ Nonsignificant or significant at $P \leq 0.001$, respectively.

Table 2. Mean number (SD) of staminate and pistillate flowers and mean number of fruit (SD) per running meter in four melon cultivars grown at five salt concentrations in irrigation water. The data are pooled from results of 11 census dates spread over 28 days; $n=55$.

\begin{tabular}{lccc}
\hline & \multicolumn{3}{c}{ No. of } \\
\cline { 2 - 4 } Variable & $\begin{array}{c}\text { Staminate } \\
\text { flowers }\end{array}$ & $\begin{array}{c}\text { Pistillate } \\
\text { flowers }\end{array}$ & Fruit \\
\hline Cultivar & & & \\
$\quad$ No. 1 & $43.1(1.88) \mathrm{a}^{2}$ & $3.5(0.13) \mathrm{b}$ & $3.8(0.18) \mathrm{a}$ \\
Topmark & $39.4(1.27) \mathrm{b}$ & $4.9(0.46) \mathrm{a}$ & $3.3(0.52) \mathrm{a}$ \\
Galia & $37.7(1.19) \mathrm{b}$ & $2.1(0.16) \mathrm{c}$ & $1.3(0.20) \mathrm{b}$ \\
BG-84-3 & $38.1(1.80) \mathrm{b}$ & $3.9(0.46) \mathrm{b}$ & $3.8(0.45) \mathrm{a}$ \\
Salt concn (ppm) & & & \\
700 & $38.7(1.89)$ & $4.0(1.35)$ & $2.8(1.08)$ \\
2500 & $40.5(1.35)$ & $3.9(1.33)$ & $3.0(1.22)$ \\
5000 & $38.8(1.08)$ & $3.0(1.22)$ & $3.2(1.19)$ \\
7500 & $40.3(1.74)$ & $3.4(0.97)$ & $3.1(1.14)$ \\
10000 & $39.7(3.15)$ & $4.0(0.80)$ & $3.3(1.52)$ \\
\hline
\end{tabular}

${ }^{\bar{z}}$ Mean separation within columns at $P \leq 0.05$ by LSD. count correlated significantly with census $(r=0.69, P=0.05)$.

'Galia' produced significantly fewer fruit than the other cultivars. For all four cultivars, a significant correlation was found between the number of pistillate flowers and the number of fruit $(r$ $=0.71, P=0.001)$.

Vegetative growth. No significant interaction was found between cultivar and any of the vegetative characteristics and the results presented are pooled. In all four cultivars, increasing the salt concentration significantly reduced the number of nodes on the main stems (Table 3). There were no differences in node count among the four cultivars. The number of branches on the main stem did not differ significantly with salinity level. However, there were differences among cultivars; 'Topmark' had the most and 'BG' the fewest branches. A significant negative correlation was found between length of the main stem and increased salinity. Both fresh and dry biomass had significant negative correlations with increasing salinity. In the 10,000-ppm treatment, both biomasses were $\approx 80 \%$ that of the control. The SDS are not shown, but in most cases were at least $25 \%$ of the mean.

Yield components. Increasing the salt concentration did not 
affect the number of fruit produced by any cultivar (Table 4). 'Galia' had significantly fewer fruit than the other three cultivars in all treatments. Mean fruit weight and yield significantly differed among cultivars. (Yield was determined by multiplying the mean fruit weight per salt treatment with the mean fruit count over all treatments.) At all salinity levels, 'BG' had significantly higher yields than the other three cultivars. In addition, it was the only

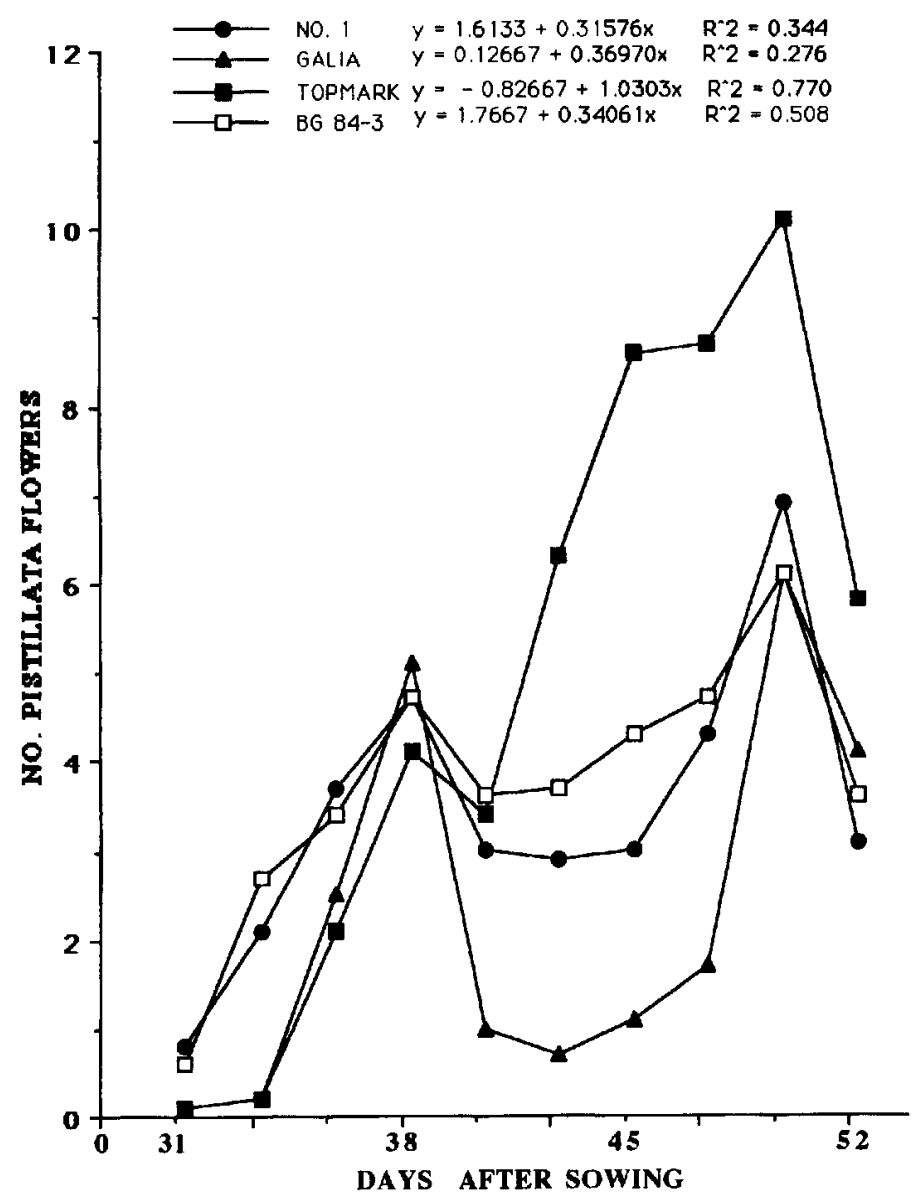

Fig. 1. The number of pistillate flowers produced at 11 census dates in four melon cultivars grown at five salt concentrations. cultivar that could be classified as salt tolerant, with a slight but nonsignificant yield reduction with increased salinity. 'No. 1', 'Topmark', and 'Galia' exhibited a significant reduction in yield with increasing salinity, although not to the same degree (Table 5). 'Galia' had a significant negative correlation between increased salinity and yield in all comparisons: Yield 3, the lowest three salinity treatments $(700,2500$, and $5000 \mathrm{ppm})$, Yield 4, the lowest four salinity treatments $(700,2500,5000$, and $7500 \mathrm{ppm})$, and Yield 5, all five salinity treatments (Table 5). 'Topmark' also had a significant negative correlation for Yield 3 and Yield 5. 'No. 1' had a significant negative correlation only at Yield 4 and Yield 5. 'BG' had no significant correlation in any comparison.

Fruit appearance and days to harvest. The appearance of the fruit in the four cultivars improved slightly with increased salinity (Table 6). This was in part due to a slight but significant increase in netting, as there was a significant correlation between percentage fruit netting and appearance $[r=(-0.88), P \leq 0.05]$. 'Topmark' had the highest percentage netting and the best appearance, whereas 'No. 1' had the lowest percent netting and the poorest appearance.

Mean days to harvest was not affected by salinity in any of the cultivars. 'No. 1' and 'BG' were harvested earlier than 'Galia' or 'Topmark'. 'BG' had the most concentrated harvest period with a significant smaller variance $(P \leq 0.05)$ than 'Galia'.

Fruit constituents. Increased salinity increased SSC and reducing sugar concentration in the fruit in all of the cultivars (Table 7). A significant positive correlation was found between SSC and reducing sugars $(r=0.88, P \leq 0.01)$. SSC rose by $0.11 \%$ per 1000 ppm salt increase in the irrigation water. 'No. 1' had a lower SSC and reducing sugar concentration than 'Galia' or 'Topmark'. Salinity did not affect acidity, EC, or $\mathrm{pH}$ of the fruit. 'Galia' and ' $\mathrm{BG}$ ' registered higher acidity and EC levels than 'No. 1' and 'Topmark'.

\section{Discussion}

The results of this study strongly support the use of moderate levels of saline water to produce muskmelons commercially, once the plants have been established, assuming an appropriate cultivar is chosen and appropriate agromanagment techniques are used. Important economic characteristics such as fruit count, number of pistillate flowers, and fruit quality, were not affected negatively by increased salinity in any of the cultivars tested. Also, the perfor-

Table 3. Vegetative characteristics of four melon cultivars grown at five salt concentrations in irrigation water and harvested 65 days after sowing. ${ }^{\mathrm{z}}$

\begin{tabular}{|c|c|c|c|c|c|}
\hline Variable & $\begin{array}{c}\text { Nodes on } \\
\text { main stem } \\
\text { (no.) }\end{array}$ & $\begin{array}{c}\text { Branches } \\
\text { on main stem } \\
\text { (no.) }\end{array}$ & $\begin{array}{l}\text { Length of } \\
\text { main stem } \\
\text { (cm) }\end{array}$ & $\begin{array}{c}\text { Fresh } \\
\text { wt } \\
(\mathrm{g})\end{array}$ & $\begin{array}{l}\text { Dry } \\
\text { wt } \\
(\mathrm{g})\end{array}$ \\
\hline \multicolumn{6}{|l|}{ Cultivar } \\
\hline No. 1 & 30.6 & $6.6 \mathrm{bc}$ & $111 \mathrm{c}$ & $1090 \mathrm{~b}$ & $110 \mathrm{c}$ \\
\hline Topmark & 30.2 & $7.2 \mathrm{a}$ & $124 \mathrm{bc}$ & $1148 \mathrm{~b}$ & $128 \mathrm{bc}$ \\
\hline Galia & 30.6 & $6.8 \mathrm{~b}$ & 144 a & $1620 \mathrm{a}$ & $163 \mathrm{a}$ \\
\hline BG-84-3 & 30.3 & $6.2 \mathrm{c}$ & $134 \mathrm{ab}$ & $1415 \mathrm{ab}$ & $151 \mathrm{ab}$ \\
\hline \multicolumn{6}{|c|}{ Salt concn (ppm) } \\
\hline 700 & $32.8 \mathrm{a}$ & 7.1 & $143 \mathrm{a}$ & $1566 \mathrm{a}$ & 160 \\
\hline 2500 & $31.1 \mathrm{ab}$ & 6.9 & $133 a b$ & $1383 \mathrm{a}$ & 144 \\
\hline 5000 & $30.0 \mathrm{bc}$ & 6.5 & $125 a b$ & $1291 \mathrm{ab}$ & 132 \\
\hline 7500 & 29.3 bc & 6.4 & $126 \mathrm{ab}$ & $1148 \mathrm{~b}$ & 127 \\
\hline 10,000 & $29.0 \mathrm{c}$ & 6.6 & $115 \mathrm{~b}$ & $1204 \mathrm{~b}$ & 128 \\
\hline$r$ & $-0.94^{*}$ & -0.80 & $-0.96^{* *}$ & $-0.90^{*}$ & $-0.90^{*}$ \\
\hline
\end{tabular}

${ }^{\mathrm{z}}$ Mean separation within columns at $P \leq 0.05$ by LSD. Data are means of five replications.

${ }^{*}, * *$ Significant at $P \leq 0.05$ or 0.01 , respectively. 
mance of 'BG' indicates that salt tolerance (with respect to yield) can be improved by breeding.

The number of fruit produced and mean fruit weight differed in their response to increased salinity. While fruit count remained unaffected in all cultivars, mean fruit weight was reduced signifi-

Table 4. Mean number of fruit, mean fruit weight, and yield of four melon cultivars grown at five salt concentrations in irrigation water. ${ }^{\mathrm{z}}$

\begin{tabular}{|c|c|c|c|c|}
\hline \multirow[b]{2}{*}{ Cultivar } & \multirow{2}{*}{$\begin{array}{c}\text { Salt } \\
\text { concn } \\
(\mathrm{ppm})\end{array}$} & \multicolumn{3}{|c|}{ Fruit yield } \\
\hline & & $\begin{array}{l}\text { No./ha } \\
(1000 \mathrm{~s})\end{array}$ & $\mathrm{kg} /$ fruit & $\mathrm{Mg} / \mathrm{ha}^{\mathrm{z}}$ \\
\hline \multirow[t]{5}{*}{ No. 1} & 700 & 24.6 & $1.465 \mathrm{a}^{\mathrm{z}}$ & $37.33 \mathrm{a}$ \\
\hline & 2500 & 21.8 & $1.467 \mathrm{a}$ & $37.41 \mathrm{a}$ \\
\hline & 5000 & 26.5 & $1.408 \mathrm{~b}$ & $35.90 \mathrm{~b}$ \\
\hline & 7500 & 26.9 & $1.325 \mathrm{c}$ & $33.79 \mathrm{c}$ \\
\hline & 10,000 & 28.0 & $1.308 \mathrm{c}$ & $33.35 \mathrm{c}$ \\
\hline \multirow[t]{5}{*}{ Topmark } & 700 & 28.4 & $1.070 \mathrm{a}$ & $30.50 \mathrm{a}$ \\
\hline & 2500 & 29.6 & $1.767 \mathrm{a}$ & $30.41 \mathrm{a}$ \\
\hline & 5000 & 27.8 & $1.045 \mathrm{a}$ & $29.78 \mathrm{a}$ \\
\hline & 7500 & 30.0 & $0.954 \mathrm{~b}$ & $27.19 \mathrm{~b}$ \\
\hline & 10,000 & 26.5 & $0.967 \mathrm{~b}$ & $27.55 b$ \\
\hline \multirow[t]{5}{*}{ Galia } & 700 & 13.4 & 1.852 & $29.26 \mathrm{a}$ \\
\hline & 2500 & 16.8 & $1.639 \mathrm{~b}$ & $25.90 \mathrm{~b}$ \\
\hline & 5000 & 15.7 & $1.503 \mathrm{c}$ & $23.75 \mathrm{c}$ \\
\hline & 7500 & 16.4 & $1.394 \mathrm{~d}$ & $22.03 \mathrm{~d}$ \\
\hline & 10,000 & 16.7 & $1.427 \mathrm{~d}$ & $22.54 \mathrm{~d}$ \\
\hline \multirow[t]{5}{*}{ BG-84-3 } & 700 & 25.2 & 1.687 & 42.00 \\
\hline & 2500 & 22.6 & 1.726 & 43.72 \\
\hline & 5000 & 26.9 & 1.651 & 41.11 \\
\hline & 7500 & 26.5 & 1.611 & 40.11 \\
\hline & 10,000 & 23.2 & 1.602 & 39.89 \\
\hline \multicolumn{5}{|l|}{ Significance } \\
\hline Cultivar & & NS & $* * *$ & $* * *$ \\
\hline Salinity & & NS & $* * *$ & $* * *$ \\
\hline Interaction & & NS & $*$ & $*$ \\
\hline
\end{tabular}

${ }^{\mathrm{z}}$ Mean separation within each cultivar at $P \leq 0.05$ by LSD.

NS $, *, * * * * *$ Nonsignificant or significant at $P \leq 0.05$ or 0.001 , respectively. cantly in three of the four cultivars examined, with the consistently high-yielding cultivar 'BG' not significantly affected by increasing salinity. Mendlinger and Pasternak (1992), Nukaya et al., (1980a), and Shannon and Francois (1978) also found that increasing salinity does not affect fruit count in melons. In contrast, DeMalach et al. (1989) and Pasternak et al. (1986b) reported that the number of onion (Allium cepa L.) bulbs and tomatoes (Lycopersicon esculentum Mill.), respectively, decreased with increasing salinity.

The differences observed in the response to increasing salinity of the four cultivars for vegetative growth and fruit yield are relevant to the question of when to test for salt tolerance in an efficient breeding program. From this study, it seems that vegetative growth characteristics may not be appropriate if fruit are the object of commerce. Salinity reduced vegetative growth by $8 \%$ to $20 \%$ in all four cultivars; from the standpoint of vegetative growth, all cultivars seemed to be salt sensitive to the same degree. This may be a species-wide phenomenon, as similar results for vegetative growth was reported by Meiri et al. (1982), Nerson and Paris (1984), and Shannon and Francois (1978). However, in respect to yield, differences were found among the cultivars with 'BG' exhibiting salt tolerance. Francois et al. (1986) examined yield and vegetative growth in wheat (Triticum aestivum L.) under salt stress and also found that vegetative growth was much more sensitive than yield to salt increases.

The improvement of some fruit quality characteristics in response to increased salt concentration and the stable expression of others is encouraging. Most important SSC increased with salinity. Mendlinger and Pasternak (1992) and Shannon and Francois (1978), although not Nukaya et al. (1980a), found similar increases in SSC with increasing salinity in melons. In tomatoes, Mizrahi et al. (1988) also found increased SSC with increased salinity. The improved appearance of the melons with increasing salinity, partly due to a small increase in percentage netting associated with salinity, was unexpected. While Mizrahi et al. (1988) reported improved appearance of tomatoes with increasing salinity, Nukaya et al. (1980a) and Shannon and Francois (1978) found that high levels of salinity reduced netting and appearance (or the percentage of marketable fruit) of the melons.

Table 5. Regression analysis of yield components in four melon cultivars grown at five salt concentrations in irrigation water. Yield-5, Yield-4, and Yield-3 represent yield over all five salinity levels (700, 2500, 5000, 7500 , and 10,000 ppm), over the lowest four and the lowest three salt concentrations, respectively."

\begin{tabular}{|c|c|c|c|c|c|c|}
\hline Cultivar & $\begin{array}{c}\text { Regression } \\
\text { statistic }^{y}\end{array}$ & $\begin{array}{c}\text { Mean } \\
\text { fruit } \\
\text { wt (kg) }\end{array}$ & $\begin{array}{c}\text { Fruit/ } \\
\text { ha (no.) }\end{array}$ & $\begin{array}{l}\text { Yield-5 } \\
\left(\mathrm{tha}^{-1}\right)\end{array}$ & $\begin{array}{l}\text { Yield-4 } \\
\left(\mathrm{t} \cdot \mathrm{ha}^{-1}\right)\end{array}$ & $\begin{array}{l}\text { Yield-3 } \\
\left(\mathrm{t} \cdot \mathrm{ha}^{-1}\right) \\
\end{array}$ \\
\hline \multirow[t]{3}{*}{ No. 1} & $r$ & $0.97^{* *}$ & 0.80 & $-0.974^{* *}$ & $-0.950^{*}$ & -0.890 \\
\hline & a & 1.495 & 22,860 & 38.10 & 38.24 & 37.83 \\
\hline & b & 0.021 & 524 & -0.050 & -0.054 & -0.035 \\
\hline \multirow[t]{3}{*}{ Topmark } & $r$ & $-0.91^{*}$ & -0.41 & $-0.914^{*}$ & -0.903 & -0.951 \\
\hline & $\mathrm{a}$ & 1.091 & 29,250 & 31.09 & 31.32 & 30.70 \\
\hline & $\mathrm{b}$ & 0.0014 & 154 & -0.039 & -0.047 & -0.017 \\
\hline \multirow[t]{3}{*}{ Galia } & $r$ & $0.94^{*}$ & 0.65 & $-0.13^{*}$ & -0.973 & $-0.980^{*}$ \\
\hline & a & 1.800 & 14,530 & 28.34 & 29.25 & 29.73 \\
\hline & $\mathrm{b}$ & 0.0045 & 247 & -0.07 & -0.102 & -0.126 \\
\hline \multirow[t]{3}{*}{ BG-84-3 } & $r$ & 0.87 & 0 & -0.819 & -0.746 & -0.422 \\
\hline & a & 1.719 & 24,880 & 43.125 & 43.25 & 42.99 \\
\hline & b & 0.0012 & 0 & -0.034 & -0.039 & -0.026 \\
\hline
\end{tabular}

${ }^{\mathrm{z}}$ Data are means of five replications.

${ }^{y} r=$ Correlation coefficient, $\mathrm{a}=\mathrm{y}$ intercept, $\mathrm{b}=$ regression coefficient.

*Significant at $P \leq 0.05$. 


\section{Literature Cited}

DeMalach, Y., D. Pasternak, S. Mendlinger, I. Borovic, and N. Abd El Salam. 1989. Irrigation with brackish water under desert conditions: VIII. Further studies on onion (Allium cepa L.). Production with brackish water. Agr. Water Mgt. 15:248-259.

Francois, L.E., E.V. Mass, T.J. Donovan, and V.L. Young. 1986. Effect of salinity on grain yield, quality, vegetative growth and germination on semi dwarf and durum wheat. Agron J. 78:10531058.

Greenway, H. and R. Munns. 1980. Mechanisms of salt tolerance in nonhalophytes. Annu. Rev. Plant Physiol. 31:149-190.

Mangal, J.L., P.S. Hooda, and S. Lal. 1988. Salt tolerance of five muskmelon cultivars. J. Agr. Sci. 110:641-643.

Table 6. Percentage netting (SD), appearance (SD), and mean days to harvest (SD) of four melon cultivars at five salt concentrations in irrigation water. $^{\mathrm{Z}}$

\begin{tabular}{lccc}
\hline \hline Treatment & Netting (\%) & Appearance $^{\mathrm{y}}$ & $\begin{array}{c}\text { Days to } \\
\text { harvest }\end{array}$ \\
\hline Cultivar & $70.4(2.29) \mathrm{d}$ & $2.4(0.38) \mathrm{a}$ & $80.7(0.92) \mathrm{d}$ \\
$\quad$ No. 1 & $97.3(0.10) \mathrm{a}$ & $1.3(0.16) \mathrm{d}$ & $90.7(0.72) \mathrm{a}$ \\
$\quad$ Topmark & $74.8(6.10) \mathrm{c}$ & $1.8(0.17) \mathrm{c}$ & $85.5(1.42) \mathrm{b}$ \\
Galia & $88.3(2.38) \mathrm{b}$ & $1.9(0.21) \mathrm{b}$ & $82.5(0.25) \mathrm{c}$ \\
$\quad$ BG-84-3 & & & \\
Salt concn (ppm) & $79.9(13.9) \mathrm{b}$ & $2.2(0.53) \mathrm{a}$ & $84.7(4.00)$ \\
700 & $84.0(2.35) \mathrm{a}$ & $1.9(0.67) \mathrm{b}$ & $84.7(5.20)$ \\
2500 & $83.0(13.3) \mathrm{ab}$ & $1.8(0.48) \mathrm{c}$ & $85.0(4.34)$ \\
5000 & $82.6(13.56) \mathrm{ab}$ & $1.7(0.34) \mathrm{c}$ & $85.1(4.47$ \\
7500 & $84.1(11.48) \mathrm{a}$ & $1.7(0.29) \mathrm{c}$ & $84.0(4.09)$ \\
10,000 & $0.61^{\mathrm{Ns}}$ & $-0.92^{*}$ & $0.39^{\mathrm{Ns}}$ \\
$r$ & &
\end{tabular}

${ }^{\mathrm{z}}$ Mean separation within columns at $P \leq 0.05$ by LSD.

yPerfect $=1$, unmarketable $=5$.

Ns, ${ }^{*}$ Nonsignificant or significant at $P \leq 0.05$, respectively.
Mass, E.V. and G.J. Hoffman. 1977. Crop salt tolerance-Current assessment. J. Irr. Drain Div. Amer. Soc. Chem. Eng. 103:115-134.

Meiri, A., G.J. Hoffman, M.C. Shannon, and J.A. Poss. 1982. Salt tolerance of two muskmelon cultivars under two radiation levels. J. Amer. Soc. Hort. Sci. 107:1168-1172.

Mendlinger, S. and D. Pasternak. 1992. Screening for salt tolerance in melons. HortScience 27:905-907.

Mizrahi, Y., E. Taleisnik, V. Kagan-Zur, Y. Zohar, R. Offenbach, E. Matan, and R. Golan. 1988. A saline irrigation regime for improving tomato fruit quality without reducing yield. J. Amer. Soc. Hort. Sci. 113:202-205.

Nerson, H. and H.S. Paris. 1984. Effects of salinity on germination, seedling growth and yield in melons. Irr. Sci. 5:265-269.

Nukaya, A., M. Masui, and A. Ishida. 1980a. Salt tolerance of muskmelons grown in different media. J. Jpn. Soc. Hort. Sci. 49:354-360.

Nukaya, A., M. Masui, and A. Ishida. 1980b. Salt tolerance of muskmelons grown in sand and nutrient solution cultures. J. Jpn. Soc. Hort. Sci. 49:93-101.

Pasternak, D. 1987. Salt tolerance and crop production-A comprehensive approach. Annu. Rev. Phytopathol. 25:271-291.

Pasternak, D., A. Azoulai, A. Danon, S. Levi, Y. DeMalach, and D. Shalev. 1986a. Irrigation with brackish water under desert conditions. VI. Automated systems to produce a range of salt concentrations in irrigation water for experimental plots. Agr. Water Mgt. 12:137-147.

Pasternak, D., Y. DeMalach, and I. Borovic. 1986b. Irrigation with brackish water under desert conditions. VII. Effect of time of application of brackish water on production of processing tomatoes (Lycopersicon esculentum Mill) Agr. Water Mgt. 12:149-158.

Shannon, M., G. Bohn, and J. McCreight. 1984. Salt tolerance among muskmelon genotypes during seed emergence and seedling growth. HortScience 19:828-830.

Shannon, M. and L. Francois. 1978. Salt tolerance of three muskmelon cultivars. J. Amer. Soc. Hort. Sci. 103:127-130.

Table 7. Fruit constituents of four melon cultivars tested at five salt concentrations in irrigation water. For the cultivars, the upper line represents the mean (SD) and lower line the correlation coefficient, $r$. For the salt treatments, the means (SD) are presented first and the correlation coefficients follows. ${ }^{\mathrm{z}}$

\begin{tabular}{|c|c|c|c|c|c|}
\hline Treatment & $\begin{array}{l}\text { TSS } \\
(\%) \\
\end{array}$ & $\begin{array}{c}\text { Acidity } \\
(\% \text { citric acid } \\
\times 100) \\
\end{array}$ & $\begin{array}{c}\mathrm{EC} \\
\left(\mathrm{dS} \cdot \mathrm{m}^{-1}\right)\end{array}$ & $\mathrm{pH}$ & $\begin{array}{c}\text { Reducing } \\
\text { sugars } \\
\left(\mathrm{mg} \cdot \mathrm{g}^{-1} \text { fresh } \mathrm{wt}\right)\end{array}$ \\
\hline \multicolumn{6}{|l|}{ Cultivar } \\
\hline No. 1 & $\begin{array}{c}7.41(0.368) b \\
0.69^{*}\end{array}$ & $\begin{array}{c}3.8(0.45) \mathrm{b} \\
0.39^{\mathrm{NS}}\end{array}$ & $\begin{array}{c}3.68(0.202) b \\
0.02^{\mathrm{NS}}\end{array}$ & $\begin{array}{c}6.16(0.073) b \\
-0.94^{*}\end{array}$ & $\begin{array}{c}0.46(0.003) \mathrm{c} \\
0.84^{*}\end{array}$ \\
\hline Topmark & $\begin{array}{c}9.18(0.642) \mathrm{a} \\
0.82^{*}\end{array}$ & $\begin{array}{c}4.2(0.45) \mathrm{b} \\
-0.66^{*}\end{array}$ & $\begin{array}{c}3.95(0.301) b \\
-0.08^{\mathrm{NS}}\end{array}$ & $\begin{array}{c}6.30(0.034) \mathrm{a} \\
-0.03^{\mathrm{Ns}}\end{array}$ & $\begin{array}{c}0.51(0.003) \mathrm{b} \\
-0.11^{\mathrm{NS}}\end{array}$ \\
\hline Galia & $\begin{array}{c}9.18(0.685) \mathrm{a} \\
0.08^{\mathrm{NS}}\end{array}$ & $\begin{array}{c}5.2(0.45) \mathrm{a} \\
0.35^{\mathrm{Ns}}\end{array}$ & $\begin{array}{c}4.34(0.637) \mathrm{a} \\
0.46^{\mathrm{Ns}}\end{array}$ & $\begin{array}{c}5.98(0.163) \mathrm{d} \\
-0.72^{\mathrm{Ns}}\end{array}$ & $\begin{array}{c}0.56(0.003) \mathrm{a} \\
0.51^{\mathrm{Ns}}\end{array}$ \\
\hline BG-84-3 & $\begin{array}{c}8.65(0.936) a b \\
0.85^{*}\end{array}$ & $\begin{array}{c}5.2(0.45) \mathrm{a} \\
0.00\end{array}$ & $\begin{array}{c}4.32(0.137) \mathrm{a} \\
0.08^{\mathrm{NS}}\end{array}$ & $\begin{array}{c}6.08(0.058) \mathrm{c} \\
0.21^{\mathrm{Ns}}\end{array}$ & $\begin{array}{c}0.54(0.004) \mathrm{a} \\
0.72^{*}\end{array}$ \\
\hline \multicolumn{6}{|c|}{ Salt concn (ppm) } \\
\hline 700 & $7.97\left(0.885^{*}\right) b$ & $4.5(0.58)$ & $3.98(0.469)$ & $6.14(0.136)$ & $0.50(0.045) \mathrm{b}$ \\
\hline 2500 & $8.35(1.084) \mathrm{ab}$ & $4.0(0.82)$ & $4.05(0.607)$ & $6.18(0.084)$ & $0.51(0.042) \mathrm{ab}$ \\
\hline 5000 & $8.81(1.019) \mathrm{a}$ & $4.3(.50)$ & $3.99(0.401)$ & $6.20(0.103)$ & $0.53(0.058) \mathrm{ab}$ \\
\hline 7500 & $8.91(0.665) \mathrm{a}$ & $4.5(1.00)$ & $4.34(0.461)$ & $6.08(0.023)$ & $0.52(0.069) \mathrm{b}$ \\
\hline 10,000 & $9.00(0.982) \mathrm{a}$ & $4.3(.50)$ & $3.96(.413)$ & $6.06(.018)$ & $0.55(.029) \mathrm{a}$ \\
\hline$r$ & $0.94^{*}$ & $0.04^{\mathrm{NS}}$ & NS & $0.71^{\mathrm{NS}}$ & $0.83^{\mathrm{Ns}}$ \\
\hline
\end{tabular}

${ }^{\mathrm{z}}$ Data are means of three randomly selected fruits per cultivar per salt treatment. Mean separation within categories at $P \leq 0.05$ by LSD.

${ }^{\mathrm{Ns},{ }^{*}}$ Nonsignificant or significant at $P \leq 0.05$, respectively. 